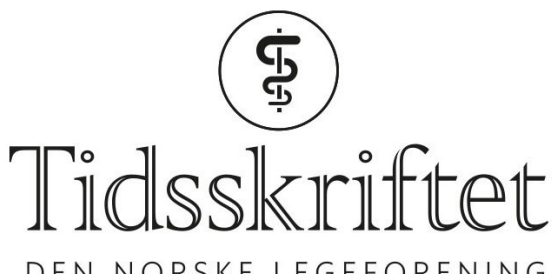

\title{
Cohens kappa - et mål på samsvar mellom observatører
}

RETTELSE

STIAN LYDERSEN

Tidsskr Nor Legeforen 2018. doi:10.4045/tidsskr.17.0962

I Tidsskriftet nr. 5/2018 s. 467 første spalte, tredje avsnitt skal det stå 55 istedenfor 45 to steder:

$22+16+5+8+4=55$ barn, dvs. en andel på $\mathrm{p}_{\mathrm{o}}=55 / 79=0,70$

Vi beklager feilen, den er rettet på nett.

Publisert: 17. april 2018. Tidsskr Nor Legeforen. DOI: 10.4045/tidsskr.18.0256

(C) Tidsskrift for Den norske legeforening 2020. Lastet ned fra tidsskriftet.no 